Article

\title{
Quality Determinants and Effect of Therapeutic Properties in Honey Consumption. An Exploratory Study on Italian Consumers
}

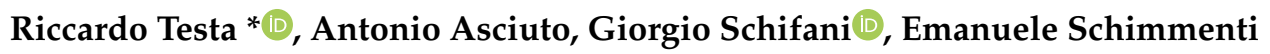 \\ and Giuseppina Migliore $(\mathbb{D}$ \\ Department of Agricultural, Food and Forestry Sciences, University of Palermo, Viale delle Scienze 13, \\ Building 4, 90128 Palermo, Italy \\ * Correspondence: riccardo.testa@unipa.it; Tel.: +39-091-2389-6624
}

Received: 24 June 2019; Accepted: 5 August 2019; Published: 7 August 2019

\begin{abstract}
Nowadays, more and more consumers show a growing interest in healthy food products that may help to maintain or improve human health, such as honey. Honey has always represented a fundamental component of traditional medicine in many world cultures. However, only thanks to several studies carried out in the last years, its use is considered as an alternative and complementary medicine, namely apitherapy. In this way, honey is recognized increasingly by consumers not only as a natural alternative to refined sugar but as healthy food, as shown by determining an increase of its consumption worldwide. This study aims to explore the consumers' determinants of honey consumption, trying to understand whether, and how much, therapeutic properties of honey affect the Italian consumers' choices. The findings of this study, although exploratory, provide information on which quality characteristics influence honey consumption in Italy, revealing that, among quality attributes, the therapeutic properties of honey play an important role in affecting consumers' behavior, followed by income, variety and taste. This could have some implications for producers and marketers as this information could contribute to defining effective marketing strategies for communicating to consumers the quality attributes of honey and its therapeutic benefits.
\end{abstract}

Keywords: apitherapy; healthy food; consumers' behavior; ordered logistic regression; frequency of consumption; online survey

\section{Introduction}

Over the last years, the concept of quality for food products has changed among consumers, not including only general attributes such as taste, price and food safety but also subjective ones related to environmental, social and ethical issues and/or intrinsic characteristics of food products [1-3]. Among the latter, several studies revealed that consumers show a growing interest in healthy food products that may help to maintain or improve human health $[4,5]$. This has important implications in the demand for food products, influencing the food markets and producers' marketing strategies [6-8].

Nowadays a greater number of consumers consider that food does not provide only nutrients for organic needs, but it must be able to promote health, improving general well-being and reducing the risk of developing certain illnesses [9]. Therefore, the classical concept of "adequate nutrition" has been replaced by the concept of "optimal nutrition" [10].

In this context, among healthy foods, consumers have shown an increasing interest towards honey and other bee products, as their use is considered as an alternative and complementary medicine, namely apitherapy [11,12].

In fact, several studies have established that honey can be classified as a complex food regarding standards for nutrients, but also as a healthy product for its beneficial effects on human health thanks to 
its numerous therapeutic properties $[13,14]$. In this context, more and more consumers have changed their perception of honey and recognize it not only as a natural alternative to refined sugar but as a healthy food [15] that has recently also become part of the Mediterranean diet [16]. This has caused a restarting of honey consumption in the last decades after having considered it for a long time, like white sugar, a high-calorie food [17].

Among bee products, in fact, honey represents the most important one in terms of quantity, consumption and profitability in the beekeeping sector [18] and the increasing consumers' interest towards honey is evident, taking into consideration that its positive supply trend occurs in the last years. According to the latest available data, the world production of honey accounts for 1.9 million tons, denoting in the last decade (1998-2017) an increase of 55.8\% [19]. This positive trend is due essentially to Asia (+128.8\%), which in 2017 represents the main production area (49.3\% of world production), followed by Europe (20.9\%) and Africa (10.7\%).

The increasing importance of honey among the agri-food products has evoked in the last years the interest of several researchers, who analyze the most important factors influencing consumers' behavior [20-23]. However, few studies have analyzed the effect of therapeutic properties on consumption behavior [24,25]. Furthermore, to the best of our knowledge, no study has been carried out to understand how Italian consumers respond to these quality attributes of honey. In order to fill up this scientific gap, this study aims to explore the consumers' determinants in purchasing honey, trying to understand whether and how therapeutic properties of honey affect the Italian consumers' choices. The findings of this study, although exploratory, provide information on which quality characteristics influence honey consumption in Italy, revealing that, among quality attributes, the therapeutic properties of honey play an important role in affecting consumer behavior. This could have some implications for producers and marketers as this information could contribute to defining effective marketing strategies for communicating to consumers the quality attributes of honey and its therapeutic benefits.

\section{Therapeutic Properties of Honey: A Brief Review}

The first tangible evidence of honey in the human diet is dated to 25,000 years ago [26]. However, although honey has always been considered important in human nutrition and is mainly used as a natural sweetener [27], it represents also a fundamental component of traditional medicine in many world cultures [28-30]. The consumption of honey for therapeutic purposes, in fact, dates back to the time of Egyptian papyrus and it is mentioned also in ancient Chinese medicine and Greek and Hindu writings [31].

Honey is composed of at least 181 components and is basically a solution supersaturated in sugars (especially fructose and glucose), where the moisture content is about $17 \%$, and containing a great variety of minor components, such as phenolic acids and flavonoids, the glucose oxidase and catalase enzymes, ascorbic acid, carotenoids, organic acids, amino acids, proteins and $\alpha$-tocopherol [32,33].

All these components confer several therapeutic properties on honey, which have been analyzed and ascertained by several studies. However, honey composition is not standard but depends on many factors, such as source-type of honey, soil and climate, genetic factors and processing methods [34,35].

One of the main characteristics of honey is its antioxidant capacity, attributed to its polyphenolic content, namely flavonoids and phenolic acids [36,37]. This property contributes to the prevention of some illnesses, such as cardiovascular diseases, cancer and diabetes, by protecting cell defense systems against the damage caused by free radicals and other oxidative agents [38].

Another therapeutic property of honey is its antimicrobial potential, mostly against gram-positive bacteria, important for controlling infections and wound healing [39]. This is due to its peroxide antibacterial action and to other substances involved such as some aromatic acids [40] and compounds with different chemical properties [41], but also to the high sugar concentration of honey and its low $\mathrm{pH}$ and high osmolarity [42]. Honey has also an antiviral and fungicide activity, thanks to its characteristic flavonoids, like chrysin, acacetin and apigenin [43]. 
Moreover, several studies have highlighted that honey has considerable anti-inflammatory properties, due mainly to the presence of flavonoids (i.e., galangin), which inhibit the development of inflammation, inhibiting cyclooxygenase and lipo-oxygenase activity, related to the inflammatory process [44].

Previous studies have shown the immunomodulatory and antitumor effects of honey, as it stimulates an increase in monocytes, lymphocyte and eosinophil serum percentages and also may prevent cancer-related processes in breast, prostate and endometrial cancer cells [45,46].

Finally, in the literature, there are some scientific papers dealing with anti-hypertensive and anti-allergic activities derived from the heating process [32] and prebiotic effects thanks to the content of oligosaccharides [47].

\section{Consumption of Honey: Theoretical Framework}

Considering the constant growth of honey market, over the last years, many scientific papers have dealt with consumers' attitudes towards the purchasing and consumption of honey, analyzing the most important factors influencing consumers' behavior. In many studies, the most important honey quality characteristics, which have been recognized in the literature and showing an effect on consumers' choice, deal with some extrinsic and intrinsic quality attributes.

In more depth, according to previous studies [20,23], consumers are interested primarily in the price and origin of honey, while the color affects consumers' subjective perception of honey quality during purchase. Similarly, Murphy and colleagues [48], by interviewing Irish consumers, showed that price, color and origin of products were quality attributes strongly affecting consumers' choice. This is also consistent with Ismaiel and colleagues [49], who in Saudi Arabia showed how honey price, color, varieties and taste, among the others, are important determinants of the consumers' demand for honey. Other studies show that consumers assign a very important factor in their purchase decision process to local food quality, not only in terms of honey origin but also in terms of more subjective attributes closely linked to the social and environmental aspects of products [21]. Beyond price, which in some cases represents a barrier for consumers' purchase intention [50], Pocol and Marghitas [51] pointed out that some honey quality attributes could have an effect on consumers' choice, among which packaging, brand and labels. In a study involving honey consumers in Western Australia, Batt and Liu [52] have shown that honey is recognized as an important natural sweetener and product origin plays an important role in consumers' purchasing decisions. As regards the socio-demographic characteristics, the literature denotes that despite the absence of a standardized consumer profile, factors that positively influence honey consumption are age, female sex, high educational level and income [53,54].

Moreover, among the intrinsic quality attributes, therapeutic properties play an increasingly important role in honey consumers' behavior. In fact, these proprieties have further increased the interest of consumers towards honey in the last years, essentially due to a twofold reason. On the one hand, consumers have positively changed their perceptions towards traditional and alternative medicine, attributing greater importance to honey consumption [9]. On the other hand, thanks to several scientific papers, the therapeutic properties and health benefits of honey are fairly well known by consumers, causing also its recent introduction in the Mediterranean diet [55].

One of the first studies dealing with the therapeutic properties of honey has been carried out in north-west Romania by Pocol and Bolboacă [24], who have shown that the origin of honey is an important quality attribute but that its consumption is mainly associated with the perceived health benefits, recognized by $88 \%$ of surveyed consumers. Similarly, Guziy et al. [56] affirm that honey consumption has an increasing tendency in Slovakia and Russia because more and more consumers consider honey as a healthy alternative to refined sugar. This is in line with Kowalczuk et al. [25], who have highlighted that for Polish consumers health benefits are one of the most important factors in honey purchasing and that many of them consume it also for medical purposes. 


\section{Materials and Methods}

In order to explore which quality determinants affect honey consumption, and how therapeutic properties affect this behavior, an online survey was performed, involving a convenient sample of 265 Italian consumers. Data were collected between spring and autumn 2018, and participants were recruited through invitations to participate in the online survey. In more detail, a snowball sampling recruitment technique was adopted to reach a large number of participants. It is worth noting that, despite this technique does not provide a fully representative sample, it allowed collection of a wide variety of information in a short period of time $[57,58]$. What emerges is that this study is explorative in nature, aimed at analyzing the relationships between honey quality characteristics and consumer behavior, therefore it does not provide conclusive results $[59,60]$.

For the survey, a questionnaire, organized in three sections, was adopted. In the first section, information was collected regarding the frequency of honey consumption, honey consumption habit (as a sweetener of herbal teas, tea, coffee or as an ingredient in cakes or other food preparations) and the main occasion for consuming it (for breakfast or other occasions). The second section of the questionnaire was reserved to gather information about the level of importance of some quality characteristics of honey, including taste, therapeutic properties (which were defined and posed to respondents as a set of antioxidant, antimicrobial, anti-inflammatory, anti-hypertensive and anticancer properties), natural sweetness, variety, color, brand, price, organic certification and Italian origin (categorical variables). The level of importance was measured using a Likert scale ranging from 1 to 5 , where 1 meant not important at all and 5 extremely important (Table 1). The third section of the questionnaire included participants socio-demographic indicators, such as age, gender, education (in four categories: Primary school, lower secondary school, upper secondary school and university degree or higher), number of household members and household monthly net income measured in euros.

Table 1. Variables of honey quality characteristics.

\begin{tabular}{ccccc}
\hline Variables & Mean & Std. Dev. & Min & Max \\
\hline Taste & 4.026 & 1.099 & 1 & 5 \\
Therapeutic & 4.098 & 1.033 & 1 & 5 \\
properties & 4.219 & 1.079 & 1 & 5 \\
Natural sweetener & 3.902 & 1.047 & 1 & 5 \\
Variety & 3.570 & 1.024 & 1 & 5 \\
Color & 3.174 & 1.412 & 1 & 5 \\
Brand & 3.468 & 1.151 & 1 & 5 \\
Price & 4.068 & 1.133 & 1 & 5 \\
Organic & 3.977 & 1.203 & 1 & 5 \\
certification & & & & \\
Italian origin & & &
\end{tabular}

In order to investigate quality characteristics affecting the frequency of honey consumption, and to understand whether and how much therapeutic properties affect consumers' behavior, an ordered logistic econometric model was applied. It can be considered as a generalization of a logit model, allowing ordered categories of a dependent variable to be modelled as a sequence of latent variables, $y^{*}$, through increasing threshold levels [61]. For the $i$-th individual, the following is specified:

$$
y_{i}^{\prime}=x_{i}^{\prime} \beta+u_{i}
$$

An ordered model with $m$ alternatives may be expressed as:

$$
y_{i}=j \quad \text { if } \quad \alpha_{j-1}<y_{i}^{\prime} \leq \alpha_{j}, j=1, \ldots, m
$$

where $\alpha_{0}=-\infty$ e $\alpha_{m}=\infty$. 
Therefore,

$$
\begin{aligned}
& \operatorname{Pr}\left(y_{i}=j\right)=\operatorname{Pr}\left(\alpha_{j-1}<y_{i}^{*} \leq \alpha_{j}\right) \\
& \quad=\operatorname{Pr}\left(\alpha_{j-1}<x_{i}^{\prime} \beta+u_{i} \leq \alpha_{j}\right) \\
& =\operatorname{Pr}\left(\alpha_{j-1}-x_{i}^{\prime} \beta<u_{i} \leq \alpha_{j}-x_{i}^{\prime} \beta\right) \\
& \quad=F\left(\alpha_{j}-x_{i}^{\prime} \beta\right)-F\left(\alpha_{j-1}-x_{i}^{\prime} \beta\right)
\end{aligned}
$$

where $F$ is the cumulative distribution function of $u_{i}$. The regression parameters, $\beta$, and the $m-1$ threshold parameters, $\alpha_{1}, \ldots, \alpha_{(\mathrm{m}-1)}$, are obtained by maximizing the log-likelihood function with $p_{i j}=\operatorname{Pr}\left(y_{i}=j\right)$. In the case of the ordered logit model used, $u$ is distributed as a logistic $F(z)=$ $e^{z} /\left(1-e^{z}\right)[62]$.

The dependent variable was constructed as the monthly frequency of honey consumption. This was subdivided into three categories by increasing levels of consumption: 'Low', frequency of honey consumption less than twice per month; 'Medium', frequency of honey consumption between 3 and 4 times per month; and 'High', frequency of honey consumption higher than 4 times per month.

Finally, in order to understand how quality characteristics, and which specific therapeutic properties affect the frequency of honey consumption, the odds ratios (ORs) were also determined by measuring the changes in probability of the dependent variable following a unit change in the regressor or independent variable. An additional advantage of this specification is that it can provide valuable information about the effects of quality characteristics on consumers' behavior.

The econometric analysis was performed by using STATA 11 statistical software.

\section{Results}

Of the 265 consumers interviewed, $67.6 \%$ were females, while males accounted for $32.5 \%$ (Table 2 ).

Table 2. Socio-demographic characteristics of interviewees.

\begin{tabular}{ccc}
\hline Variables & Items & $\%$ \\
\hline \multirow{2}{*}{ Gender } & Male & 32.5 \\
& Female & 67.6 \\
\hline \multirow{2}{*}{ Age (year) } & $18-24$ & 15.8 \\
& $25-44$ & 46.0 \\
& $45-64$ & 34.7 \\
Education & $65-74$ & 3.4 \\
\hline \multirow{2}{*}{ tousehold monthly income (euro) } & Lower secondary school & 6.8 \\
& Upper secondary school & 41.9 \\
& University & 32.1 \\
& Master's degree and PhD & 19.2 \\
\hline \multirow{2}{*}{ Hour } & $<1300$ & 7.2 \\
& $1300-2000$ & 16.6 \\
& $2001-2700$ & 21.5 \\
& $2701-3400$ & 19.3 \\
& $3401-4100$ & 21.1 \\
& $4101-4800$ & 7.6 \\
& $>4800$ & 6.8 \\
\hline
\end{tabular}

The average age of respondents was equal to 39.9 years and the majority of them were $25-44$ years old ( $46.0 \%$ of interviewees), followed by $45-64$ years old (34.7\%). The sample showed a high level of education, as more than half had a bachelor's degree, a master's degree or a $\mathrm{PhD}$. As regards the household monthly income, $21.5 \%$ of respondents declared a value ranging from 2001 euros to 2700 euros, followed by the $3401-4100$ range $(21.1 \%)$, while the average value was equal to 3804 euros. 
By analyzing the dependent variable, it emerges that just over a third of the participants said they consume honey less than twice a month; however, $37.4 \%$ claimed to have a consumption frequency higher than four times per month (Table 3).

Table 3. Distribution of the three categories of the dependent variable.

\begin{tabular}{ccc}
\hline Frequency of Consumption & Freq. & Percent \\
\hline Low (less than twice a month) & 92 & 34.7 \\
Medium (between 3 and 4 times per month) & 74 & 27.9 \\
High (higher than 4 times per month) & 99 & 37.4 \\
\hline Total & $\mathbf{2 6 5}$ & $\mathbf{1 0 0 . 0}$ \\
\hline
\end{tabular}

In order to understand which quality characteristics of honey and, in particular, which therapeutic properties affect consumers' behavior, the results of the econometric model (Table 4) showed that the frequency of honey consumption among respondents increase with the rise of the explanatory variables, apart from color.

Table 4. Results of the econometric model (ordered logistic regression).

\begin{tabular}{|c|c|c|c|c|c|c|}
\hline Log likelihood $=-235.51476$ & \multirow[b]{2}{*}{ Coef. } & \multirow[b]{2}{*}{ Std. err. } & \multirow[b]{2}{*}{$z$} & \multirow[b]{2}{*}{$p>|z|$} & \multicolumn{2}{|c|}{$\begin{array}{c}\text { Number of obs }=265 \\
\text { LR chi2 }(13)=77.39 \\
\text { Prob }>\text { chi2 }=0.0000 \\
\text { Pseudo R2 }=0.1411\end{array}$} \\
\hline Frequency of consumption & & & & & 95\% Conf. & Interval \\
\hline Therapeutic properties & 0.591 & 0.139 & 4.26 & 0.000 & 0.319 & 0.864 \\
\hline Taste & 0.378 & 0.146 & 2.59 & 0.010 & 0.092 & 0.665 \\
\hline Natural sweetener & 0.255 & 0.139 & 1.84 & 0.066 & -0.017 & 0.526 \\
\hline Variety & 0.394 & 0.143 & 2.75 & 0.006 & 0.114 & 0.675 \\
\hline Color & -0.320 & 0.134 & -2.39 & 0.017 & -0.583 & -0.058 \\
\hline Brand & -0.107 & 0.098 & -1.08 & 0.279 & -0.300 & 0.086 \\
\hline Price & -0.096 & 0.116 & -0.83 & 0.409 & -0.324 & 0.132 \\
\hline Organic certification & 0.132 & 0.135 & 0.98 & 0.027 & -0.132 & 0.397 \\
\hline Italian origin & -0.100 & 0.126 & -0.79 & 0.431 & -0.347 & 0.148 \\
\hline Gender $(1=$ female $; 0=$ male $)$ & 0.390 & 0.269 & 1.45 & 0.148 & -0.138 & 0.918 \\
\hline Age & 0.027 & 0.010 & 2.79 & 0.005 & 0.008 & 0.046 \\
\hline Education level & -0.001 & 0.151 & 0.00 & 0.996 & -0.297 & 0.296 \\
\hline Income & 0.139 & 0.080 & 1.74 & 0.082 & -0.095 & 0.218 \\
\hline Threshold 1 & 4.674739 & 1.101118 & & & 2.516588 & 6.83289 \\
\hline Threshold 1 & 7.28517 & 1.159968 & & & 5.011674 & 9.558666 \\
\hline Frequency of consumption & Odds ratio & $p>|z| \S$ & & & 95\% Conf. & Interval \\
\hline Therapeutic properties & 1.806 & $* * *$ & & & 1.376 & 2.372 \\
\hline Taste & 1.460 & $* * *$ & & & 1.096 & 1.944 \\
\hline Natural sweetener & 1.290 & $* *$ & & & 0.983 & 1.692 \\
\hline Variety & 1.483 & $* * *$ & & & 1.120 & 1.964 \\
\hline Color & 0.726 & $* *$ & & & 0.558 & 0.944 \\
\hline Brand & 0.899 & & & & 0.741 & 1.090 \\
\hline Price & 0.908 & & & & 0.723 & 1.141 \\
\hline Organic certification & 1.141 & $* *$ & & & 0.876 & 1.487 \\
\hline Italian origin & 0.905 & & & & 0.707 & 1.159 \\
\hline Gender $(1=$ female $; 0=$ male $)$ & 1.477 & & & & 0.871 & 2.504 \\
\hline Age & 1.028 & ** & & & 1.008 & 1.048 \\
\hline Education level & 0.999 & & & & 0.743 & 1.344 \\
\hline Income & 1.571 & * & & & 1.045 & 1.318 \\
\hline
\end{tabular}

$\S p>|z|$ is the level of statistical significance: $* * * 1 \%, * * 5 \%, * 10 \%$. 
The independent variables that showed a positive effect on the frequency of consumption of honey (dependent variable) are therapeutic proprieties, taste, natural sweetener, variety and organic certification. Among other independent variables, color showed to be in a negative relationship with the frequency of honey consumption, while brand, price and origin were statistically not significant.

As regards the socio-demographic variables, which were also used as independent variables in the model, only age and income increased the probability of high frequency of honey consumption. Among other socio-demographic characteristics, gender and education level were not statistically significant.

The calculation of odds ratios (ORs) allowed us to evaluate the probability of having a high frequency of honey consumption among the explanatory variables. In particular, results showed that therapeutic proprieties (understood as the set of antioxidant, antimicrobial, anti-inflammatory, anti-hypertensive and anticancer properties) showed the biggest influence on the probability of having a high frequency of honey consumption (1.80 times), followed by variety (1.48 times), taste (1.46 times) and natural sweetener (1.29 times). Finally, among the socio-demographic variables of respondents, only income showed a significant influence on the probability of having a high frequency of honey consumption with an OR value equal to 1.51 times.

\section{Discussion}

Results showed that the frequency of honey consumption is influenced by many quality attributes of honey and some socio-demographic characteristics of respondents. Among the quality attributes, the therapeutic properties of honey were the most important, as reported by previous studies $[25,63]$. Several studies, in fact, demonstrated that honey is a product with numerous therapeutic properties for human health that are able to prevent and/or treat certain diseases $[64,65]$ and consumers are more and more conscious about its health and medical benefits $[56,66]$. This result is consistent with Sacchi et al. [67] who highlighted that, nowadays, consumers are increasingly interested in food that provides health benefits by improving well-being and reducing the risk of diseases.

The increased awareness of consumers towards healthy foods is evident considering that among the socio-economic characteristics of respondents, apart from income, only an increase of age assumed a moderate role in the frequency of honey consumption, as older generations consume honey with higher frequency than younger consumers $[68,69]$. In our case, in fact, unlike previous studies [70], subjects of the female gender and high educational level were not more likely to buy healthy food, such as honey.

As mentioned above, results showed that in consumers' frequency of honey buying, household income was the second main factor, highlighting that financial and economic variables play a key role in consumers' choices [71]. This is due to the high price of honey compared to other sweeteners [50]. In particular, empirical analysis denoted that the frequency of honey consumption rose with the relative increase of household income [18]. However, results showed that price was not statistically significant in honey consumption and this was essentially due to a twofold reason. On the one hand, the medium-high value of household income of respondents (3,804 euros), denoted as higher-income consumers, are less price conscious than low-income ones in food purchasing [72]. On the other hand, the change that occurred over the last years in consumers' perceptions towards food products led them to take into consideration not only the product price but also to choose quality and healthy foods rather than quantity $[73,74]$.

Other important factors for the interviewees, as well as for previous studies [75], were represented by two intrinsic characteristics of honey: variety and taste. With regard to variety, similarly with what was reported by Schifani et al. [21], the wildflower was the most preferred honey typology for respondents, followed by citrus, eucalyptus and sulla honey varieties. The botanical source of honey assumes a very important role in consumers' choices also because it considerably influences its taste [76] that is one of the main determinants for honey purchasing and consumption [56,77].

Similar to other studies [78], respondents recognized honey as a natural sweetener and this assumed a very important factor for honey consumption. Honey, in fact, starting from the origin of 
human history, has been considered as one of the most energy-rich and sweetest foods in nature [26]. However, after the industrial revolution and the introduction of sugar cane, honey consumption decreased as it was recognized as a high-calorie food that caused weight gain similar to refined sugar [79]. In the last decades, instead, more and more consumers have preferred honey to synthetic sweeteners thanks to several studies that showed its health proprieties and its adoption in traditional and alternative medicine $[9,80]$. Moreover, the importance assigned to the origin of honey by interviewees confirms that environmental and ethical aspects are becoming an essential motivation in consumers' behavior for food products [81].

In this regard, results suggested that also organic certification represented an important factor among the motivational determinants in honey consumption. This is in line with previous studies $[82,83]$ that denoted a higher willingness to pay by consumers for organic honey and a greater consumers' demand.

As regards the color, instead, the empirical analysis showed that it did not strongly influence the consumer's choice of honey in contrast to results reported by previous studies [23,48].

Finally, although results showed that the origin of honey assumed a low level of significance, it is worth noting that this could be due to the high mean values assigned by respondents, regardless of the frequency of honey consumption. In this case, empirical analysis is in line with other studies, which denoted that the origin of honey represents a very important factor for consumers' choices [22,84].

\section{Conclusions}

Over the last years, consumers' perception of honey has significantly changed, as it is now recognized not only as a natural sweetener with a high-calorie content but even more as a healthy food. This is essentially due to several studies that have highlighted the numerous therapeutic properties of honey for human health, rediscovering its millenary adoption as an alternative and complementary medicine called apitherapy. In this context, the growing consumers' interest in healthy food products has led to an increase in honey consumption worldwide.

The empirical analysis carried out in this study showed, in fact, that therapeutic proprieties are the most important factor in honey consumption. This denotes that, nowadays, consumers are more and more conscious towards food products that do not provide only nutrients, but which are also able to promote health, improving general well-being and reducing the risk of developing certain human diseases.

To confirm that the concept of quality concerning food products has changed among consumers, results denote that other important factors in honey consumption are represented by variety, taste, natural origin and organic certification. This highlighted that also attributes related to environmental, social and ethical issues and/or intrinsic characteristics assume a key role in consumers' behavior. However, honey price seems still to be a barrier to consumption, considering that only high-income consumers showed a high frequency of consumption.

These findings could have important implications for producers and marketers in order to help them in defining effective marketing strategies for communicating to consumers honey quality attributes and its therapeutic benefits. Furthermore, this study could contribute towards the scientifically objective part of the required knowledge for business implementation and success. While these findings are not to be understood as absolute or definitive, they are sound and visibly reinforce and expand extant research on the subject.

Further research is obviously needed to overcome the limitations of the present study, which is based only on a convenient sample of Italian consumers. Accordingly, the present study is explorative in nature and aimed only at analyzing the relationships between honey quality characteristics and consumption behavior, therefore it does not provide conclusive results.

As a result, further researchers have to take into account a representative sample of Italian consumers in order to validate the findings obtained in the present study. To achieve a more exhaustive understanding of consumer behavior with regard to honey consumption, it could be interesting to 
combine quantitative and qualitative research tools, trying to better understand certain motivational and subjective aspects.

Author Contributions: This study is a result of the full collaboration of all the authors. However, R.T. conceived and designed the study, wrote the introduction and the "Therapeutic properties of honey: a brief review" section, and collaborated for the 'Results' and 'Discussion' sections, A.A. collaborated to write the 'Results' and 'Discussion' sections, E.S. and G.S. carried out the 'Conclusions' section, while G.M. wrote the 'Materials and methods' and 'Consumption of honey: theoretical framework' sections, and coordinated the study.

Funding: This research received no external funding.

Acknowledgments: The authors wish to thank Angela D'Acquisto and Pietro Romeo for their contribution during data collection.

Conflicts of Interest: The authors declare no conflict of interest.

\section{References}

1. Anklam, E. Safe Food and Healthy Diets. In Emerging and Traditional Technologies for Safe, Healthy and Quality Food; Nedović, V., Raspor, P., Lević, J., Tumbas Šaponjac, V., Barbosa-Cánovas, G., Eds.; Springer: Berlin/Heidelberg, Germany, 2016; pp. 3-8.

2. Annunziata, A.; Scarpato, D. Factors affecting consumer attitudes towards food products with sustainable attributes. Agric. Econ. 2014, 60, 353-363. [CrossRef]

3. Dowd, K.; Burke, K.J. The influence of ethical values and food choice motivations on intentions to purchase sustainably sourced foods. Appetite 2013, 69, 137-144. [CrossRef] [PubMed]

4. Teichert, T.; Mühlbach, C. The Second Health Care Market: Market Mapping Based upon Consumer Perception. Gesundheitswesen 2018, 80, 247-249. [PubMed]

5. Crofton, E.C.; Markey, A.; Scannell, A.G.M. Consumers' expectations and needs towards healthy cereal based snacks: An exploratory study among Irish adults. Br. Food J. 2013, 115, 1130-1148. [CrossRef]

6. Jezovicová, K.; Turcínková, J.; Drexler, D. The influence of package attributes on consumer perception at the market with healthy food. Acta Univ. Agric. Et Silvic. Mendel. Brun. 2016, 64, 1919-1926. [CrossRef]

7. Nielsen, K.E. Health beneficial consumer products—Status and trends. In Developing Food Products for Consumers with Specific Dietary Needs; Osborn, S., Morley, W., Eds.; Woodhead Publishing in Food Science; Tecnology and Nutrition; Elsevier: Amsterdam, The Netherlands, 2016; pp. 15-42.

8. Lee, C.M.; Moskowitz, H.R.; Lee, S.-Y. Expectations, needs and segmentation of healthy breakfast cereal consumers. J. Sens. Stud. 2007, 22, 587-607. [CrossRef]

9. Wardle, J.; Lui, C.W.; Adams, J. Complementary and alternative medicine in rural communities: Current research and future directions. J. Rural Health 2012, 28, 101-112. [CrossRef]

10. Viuda-Martos, M.; Ruiz-Navajas, Y.; Fernández-López, J.; Pérez-Álvarez, J.A. Functional Properties of Honey, Propolis, and Royal Jelly. J. Food Sci. 2008, 73, 117-124. [CrossRef]

11. Şenel, E.; Demir, E. Bibliometric analysis of apitherapy in complementary medicine literature between 1980 and 2016. Complement. Ther. Clin. Pract. 2018, 31, 47-52. [CrossRef]

12. Fratellone, P.M.; Tsimis, F.; Fratellone, G. Apitherapy products for medicinal use. J. Altern. Complement. Med. 2016, 22, 1020-1022. [CrossRef]

13. Alvarez-Suarez, J.M.; Giampieri, F.; Battino, M. Honey as a source of dietary antioxidants: Structures, bioavailability and evidence of protective effects against human chronic diseases. Curr. Med. Chem. 2013, 20, 621-638. [CrossRef] [PubMed]

14. Marghitas, L.; A.Dezmirean, D.S.; Pocol, C.B.; Ilea, M.; Bobis, O.; Gergen, I. The development of a biochemical profile of acacia honey by identifying biochemical determinants of its quality. Not. Bot. Horti Agrobot. Cluj Napoca 2010, 38, 84-90.

15. Gao, F.; Costanza, E.; Schraefel, M.C. Honey=Sugar' Means Unhealthy: Investigating How People Apply Knowledge to Rate Food's Healthiness. Available online: http://www.eprints.soton.ac.uk/338310/1/ ubicomp2012_162_honey=sugar_Gao.pdf (accessed on 6 June 2019).

16. Battino, M.; Forbes-Hernández, T.Y.; Gasparrini, M.; Afrin, S.; Cianciosi, D.; Zhang, J.; Manna, P.P.; Reboredo-Rodríguez, P.; Varela Lopez, A.; Quiles, J.L.; et al. Relevance of functional foods in the Mediterranean diet: The role of olive oil, berries and honey in the prevention of cancer and cardiovascular diseases. Crit. Rev. Food Sci. Nutr. 2019, 59, 893-920. [CrossRef] 
17. Popkin, B.M.; Gordon-Larsen, P. The nutrition transition: Worldwide obesity dynamics and their determinants. Int. J. Obes. 2004, 28, S2-S9. [CrossRef] [PubMed]

18. Roman, A.; Popiela-Pleban, E.; Kozak, M. Factors influencing consumer behavior relating to the purchasing of honey part 1. The buying process and the level of consumption. J. Apic. Sci. 2013, 57, 159-172. [CrossRef]

19. FAOSTAT. Food and Agriculture Data. Available online: http://www.fao.org/faostat/en/\#home (accessed on 11 April 2019).

20. Šánová, P.; Svobodová, J.; Hrubcová, B.; Šeráková, P. Segmentation of Honey Buyers' Behaviour by Conjoint Analysis. Sci. Agric. Bohem. 2017, 48, 55-62. [CrossRef]

21. Schifani, G.; Romeo, P.; Guccione, G.D.; Schimmenti, E.; Columba, P.; Migliore, G. Conventions of quality in consumer preference toward local honey in southern Italy. Calitatea 2016, 17, 92.

22. Wu, S.; Fooks, J.R.; Messer, K.D.; Delaney, D. Consumer demand for local honey. Appl. Econ. 2015, 47, 4377-4394. [CrossRef]

23. Gyau, A.; Akalakou, C.; Degrande, A.; Biloso, A. Determinants of Consumer Preferences for Honey in the Democratic Republic of Congo. J. Food Prod. Mark. 2014, 20, 476-490. [CrossRef]

24. Pocol, C.B.; Bolboacă, S.D. Perceptions and trends related to the consumption of honey: A case study of North-West Romania. Int. J. Consum. Stud. 2013, 37, 642-649. [CrossRef]

25. Kowalczuk, I.; Jezewska-Zychowicz, M.; Trafiałek, J. Conditions of honey consumption in selected regions of Poland. Acta Sci. Pol. Technol. Aliment. 2017, 16, 101-112.

26. Crittenden, N.A. The importance of honey consumption in Human Evolution. Food Foodways Explor. Hist. Cult. Hum. Nourishment 2011, 19, 257-273. [CrossRef]

27. Aparna, A.R.; Rajalakshmi, D. Honey-Its characteristics, sensory aspects, and applications. Food Rev. Int. 1999, 15, 455-471. [CrossRef]

28. Trumbeckaite, S.; Dauksiene, J.; Bernatoniene, J.; Janulis, V. Knowledge, Attitudes, and Usage of Apitherapy for Disease Prevention and Treatment among Undergraduate Pharmacy Students in Lithuania. Evid. Based Complement. Altern. Med. 2015, 2015, 172502. [CrossRef]

29. Zamudio, F.; Kujawska, M.; Hilgert, N.I. Honey as medicinal and food resource. Comparison between Polish and multiethnic settlements of the Atlantic Forest, Misiones, Argentina. Open Complement. Med. J. 2010, 2, 58-73. [CrossRef]

30. Gómez-Caravaca, A.M.; Gómez-Romero, M.; Arráez-Román, D.; Segura-Carretero, A.; Fernández-Gutíerrez, A. Advances in the analysis of phenolic compounds in products derived from bees. J. Pharmac. Biomed. Anal. 2006, 41, 1220-1234.

31. Bogdanov, S. Short History of Honey in Medicine; Bee Product Science: Switzerland, 2017; Available online: http://www.bee-hexagon.net/files/file/fileE/HealthHoney/9HoneyMedicineReview.pdf (accessed on 7 June 2019).

32. Nagai, T.; Kai, N.; Tanoue, Y.; Suzuki, N. Chemical properties of commercially available honey species and the functional properties of caramelization and Maillard reaction products derived from these honey species. J. Food Sci. Technol. 2018, 55, 586-597. [CrossRef]

33. Ferreres, F.; Garciaviguera, C.; Tomaslorente, F.; Tomasbarberan, F.A. Hesperetin C a marker of the floral origin of citrus honey. J. Sci. Food Agric. 1993, 61, 121-123. [CrossRef]

34. Yao, L.; Datta, N.; Tomas-Barberan, F.A.; Ferreres, F.; Martos, I.; Singanusong, R. Flavonoids, phenolic acids and abscissic acid in Australian and New Zealand Leptospermum honeys. Food Chem. 2003, 81, 159-168. [CrossRef]

35. Al-Mamary, M.; Al-Meeri, A.; Al-Habori, M. Antioxidant activities and total phenolics of different types of honey. Nutr. Res. 2002, 22, 1041-1047. [CrossRef]

36. Münstedt, K.; Bogdanov, S. Bee products and their potential use in modern medicine. J. ApiProduct ApiMed. Sci. 2009, 1, 57-63. [CrossRef]

37. Gheldof, N.; Wang, X.H.; Engeseth, N.J. Buckwheat honey increases serum antioxidant capacity in humans. J. Agric. Food Chem. 2003, 51, 1500-1505. [CrossRef]

38. Pham-Huy, L.; He, H.; Pham-Huy, C. Free Radicals, Antioxidants in Disease and Health. Int. J. Biomed. Sci. 2008, 4, 89-96.

39. Molan, P.C. The antibacterial activity of honey. Variation in the potency of the antibacterial activity. Bee World 1992, 73, 59-76. [CrossRef]

40. Russell, K.M.; Molan, P.C.; Wilkins, A.L.; Holland, P.T. Identification of some antibacterial constituents of New Zealand Manuka honey. J. Agric. Food Chem. 1988, 38, 10-13. [CrossRef] 
41. Bogdanov, S. Nature and origin of the antibacterial substances in honey. Lebensm. Wiss. Technol. 1997, 30, 748-753. [CrossRef]

42. Mundo, M.A.; Padilla-Zakour, O.I.; Worobo, R.W. Growth inhibition of foodborne pathogens and food spoilage organisms by select raw honeys. Int. J. Food Microbiol. 2004, 97, 1-8. [CrossRef]

43. Al-Waili, N.S. Topical honey applications vs. acyclovir for the treatment of recurrent herpes simplex lesions. Med. Sci. Monit. 2004, 10, 94-98.

44. Al-Waili, N.S.; Boni, N.S. Natural honey lowers plasma prostaglandin concentrations in normal individuals. J. Med. Food 2003, 6, 129-133. [CrossRef]

45. Tsiapara, A.; Jaakkola, M.; Chinou, I.; Graikou, K.; Tolonen, T.; Virtanen, V.; Moutsatsou, P. Bioactivity of Greek honey extracts on breast cancer (MCF-7), prostate cancer (PC-3) and endometrial cancer (Ishikawa) cells: Profile analysis of extracts. Food Chem. 2009, 116, 702-708. [CrossRef]

46. Abuharfeil, N.; Al Oran, L.; Abo-Shehada, M. The effects of bee honey on the proliferative activity of human B and T lymphocytes and activity of phagocytes. Food Agric. Immunol. 2008, 169-177. [CrossRef]

47. Sanz, M.L.; Polemis, N.; Morales, V.; Corzo, N.; Drakoularakou, A.; Gibson, G.R.; Rastall, R.A. In vitro investigation into the potential prebiotic activity of honey oligosaccharides. J. Agric. Food Chem. 2005, 53, 2914-2921. [CrossRef]

48. Murphy, M.; Cowan, C.; Henchion, M.; O’Reilly, S. Irish consumers' preference for honey: A conjoint approach. Br. Food J. 2000, 102, 585-597. [CrossRef]

49. Ismaiel, S.; Al Kahtani, S.; Adgaba, N.; Al-Ghamdi, A.A.; Zulail, A. Factors that affect consumption patterns and market demands for honey in the Kingdom of Saudi Arabia. Food Nutr. Sci. 2014, 5, 1725-1737. [CrossRef]

50. Arvanitoyannis, I.; Krystallis, A. An empirical examination of the determinants of honey consumption in Romania. Int. J. Food Sci. Technol. 2006, 41, 1164-1176. [CrossRef]

51. Pocol, C.B.; Marghitas, L.A. A comparison between the segmentation of honey market in Romania and Ireland. Bull. UASVM 2008, 65, 279-282.

52. Batt, P.J.; Liu, A. Consumer behaviour towards honey products in Western Australia. Br. Food J. 2012, 114, 285-297. [CrossRef]

53. Pocol, C.B. Consumer preferences for different honey varieties in the North West Region of Romania. Agron. Ser. Sci. Res. 2012, 55, 263-266.

54. Pocol, C.B.; Ványi, G.A. A comparison between Hungarian and Romanian consumption. Bull. UASVM 2012, 69, 244-252.

55. Badolato, M.; Carullo, G.; Cione, E.; Aiello, F.; Caroleo, M.C. From the hive: Honey, a novel weapon against cancer. Eur. J. Med. Chem. 2017, 142, 290-299. [CrossRef]

56. Guziy, S.; Šedík, P.; Horská, E. Comparative study of honey consumption in Slovakia and Russia. Potravin. Slovak J. Food Sci. 2017, 11, 472-479.

57. Galati, A.; Schifani, G.; Crescimanno, M.; Migliore, G. "Natural wine" consumers and interest in label information: An analysis of willingness to pay in a new Italian wine market segment. J. Clean. Prod. 2019, 227, 405-413. [CrossRef]

58. McCullough, D. Web-based market research: The dawning of a new age. Direct Mark. 1998, 61, 36-39.

59. Li, J.G.; Jia, J.R.; Taylor, D.; Bruwer, J.; Li, E. The wine drinking behaviour of young adults: An exploratory study in China. Br. Food J. 2011, 113, 1305-1317. [CrossRef]

60. Forbes, S.L.; Cohen, D.A.; Cullen, R.; Wratten, S.D.; Fountain, J. Consumer attitudes regarding environmentally sustainable wine: An exploratory study of the New Zealand marketplace. J. Clean. Prod. 2009, 17, 1195-1199. [CrossRef]

61. Migliore, G.; Romeo, P.; Testa, R.; Schifani, G. Beyond Alternative Food Networks: Understanding Motivations to Participate in Orti Urbani in Palermo. Cult. Agric. Food Environ. 2019, in press. [CrossRef]

62. Cameron, A.C.; Trivedi, P.K. (Eds.) Microeconometrics: Methods and Applications; Cambridge University Press: New York, NY, USA, 2005.

63. Brščić, K.; Šugar, T.; Poljuha, D. An empirical examination of consumer preferences for honey in Croatia. Appl. Econ. 2017, 49, 5877-5889. [CrossRef]

64. Alvarez-Suarez, J.M.; Giampieri, F.; González-Paramás, A.M.; Damiani, E.; Astolfi, P.; Martinez-Sanchez, G.; Bompadre, S.; Quiles, J.L.; Santos-Buelga, C.; Battino, M. Phenolics from monofloral honeys protect human erythrocyte membranes against oxidative damage. Food Chem. Toxicol. 2012, 50, 1508-1516. [CrossRef] 
65. Romero-Silva, S.; Angel Martinez, R.M.; Romero-Romero, L.P.; Rodriguez, O.; Gerardo Salas, C.; Morel, N.; Lopez-Munoz, F.J.; Lima-Mendoza, L.A.L.; Bravo, G. Effects of honey against the accumulation of adipose tissue and the increased blood pressure on Carbohydrate-Induced obesity in rat. Lett. Drug Des. Discov. 2011, 8, 69-75. [CrossRef]

66. Thomé, K.M.; Pinho, G.M.; Hoppe, A. Consumption values and physical activities: consumers' healthy eating choices. Br. Food J. 2019, 121, 590-602. [CrossRef]

67. Sacchi, G.; Cei, L.; Stefani, G.; Lombardi, G.; Rocchi, B.; Belletti, G.; Padel, S.; Sellars, A.; Gagliardi, E.; Nocella, G.; et al. A Multi-Actor Literature Review on Alternative and Sustainable Food Systems for the Promotion of Cereal Biodiversity. Agriculture 2018, 8, 173. [CrossRef]

68. Pocol, C.B.; Teselios, C.M. Socio-economic determinants of honey consumption in Romania. J. Food Agric. Environ. 2012, 10, 18-21.

69. Pocol, C.B. Modelling the honey consumption behaviour in Romania by using socio-demographic determinants. Afr. J. Agric. Res. 2011, 6, 4069-4080.

70. Kearney, M.; Kearney, J.M.; Dunne, A.; Gibney, M.J. Sociodemographic determinants of perceived influences on food choice in a nationally representative sample of Irish adults. Public Health Nutr. 2000, 3, 219-226. [CrossRef]

71. Gündüz, Ş.; Hakem, A.; Erdoğuş, M. Food safety knowledge, behavior and attitude of Libyan consumers. Qual. Quant. 2018, 52, 165-179. [CrossRef]

72. Steenhuis, I.H.M.; Waterlander, W.E.; De Mul, A. Consumer food choices: The role of price and pricing strategies. Public Health Nutr. 2011, 14, 2220-2226. [CrossRef]

73. Kozelová, D.; Matejková, E.; Fikselová, M.; Dékányová, J. Analysis of consumer behaviour at chocolate purchase. Potravinarstvo 2014, 8, 62-66.

74. Kuchler, F. Is it food quality or quantity that responds to changing income? Appl. Econ. Perspect. Policy 2011, 33, 205-221. [CrossRef]

75. Ványi, G.A.; Csapó, Z.; Kárpáti, L. Evaluation of consumers' honey purchase habits in Hungary. J. Food Prod. Mark. 2011, 17, 227-240. [CrossRef]

76. Escuredo, O.; Fernández-González, M.; Seijo, M.C. Differentiation of Blossom Honey and Honeydew Honey from Northwest Spain. Agriculture 2012, 2, 25-37.

77. Thrasivoulou, A. An evaluation of consumer's preferences on honey quality. Apiacta 2000, 35, 121-125.

78. Yeow, S.H.C.; Chun, S.T.S.; Yeow, J.A.; Tan, K.S. Consumer Purchase Intentions and Honey Related Products. J. Mark. Res. Case Stud. 2013, 2013, 197440. [CrossRef]

79. Allsop, K.A.; Miller, J.B. Honey revisited: A reappraisal of honey in pre-industrial diets. Br. J. Nutr. 1996, 75, 513-520. [CrossRef]

80. Mizrahi, A.; Lensky, Y. (Eds.) Bee Products: Properties, Applications, and Apitherapy; Plenum Press: New York, NY, USA, 1996.

81. Lombardi, A.; Migliore, G.; Verneau, F.; Schifani, G.; Cembalo, L. Are "good guys" more likely to participate in local agriculture? Food Qual. Prefer. 2015, 45, 158-165. [CrossRef]

82. Cosmina, M.; Gallenti, G.; Marangon, F.; Troiano, S. Attitudes towards honey among Italian consumers: A choice experiment approach. Appetite 2016, 99, 52-58. [CrossRef]

83. Jensen, J.D.; Mørkbak, M.R. Role of gastronomic, externality and feasibility attributes in consumer demand for organic and local foods: The case of honey and apples. Int. J. Consum. Stud. 2013, 37, 634-641. [CrossRef]

84. Kos Skubic, M.; Erjavec, K.; Klopčič, M. Consumer preferences regarding national and EU quality labels for cheese, ham and honey: The case of Slovenia. Br. Food J. 2018, 120, 650-664. [CrossRef]

(C) 2019 by the authors. Licensee MDPI, Basel, Switzerland. This article is an open access article distributed under the terms and conditions of the Creative Commons Attribution (CC BY) license (http://creativecommons.org/licenses/by/4.0/). 